\title{
Efficiency of biologization of intensification processes in industrial fruit growing
}

\author{
Evgeniy Egorov, Zhanna Shadrina, and Gayane Kochyan* \\ Federal State Budget Scientific Institution «North Caucasian Federal Scientific Center of \\ Horticulture, Viticulture, Wine-making», str. 40 Let Pobedy, 39, Krasnodar, 350901, Russia
}

\begin{abstract}
The intensification processes characteristic in industrial fruit growing is given, their aims are determined. The main technological shifts of the technological structure formed in the domestic fruit growing are presented. Based on the analysis of the technological structure development, the predicted technological shifts for the near future, the characteristic features of promising technologies in the fruit growing, their criteria and signs are presented. The factors-indicators of fruit growing intensification are systematically presented. A retrospective of the industrial fruit growing intensification based on the weak-growing rootstocks breeding and introduction and differentiated technologies formed with their participation is reflected. The main directions of intensification that increase the agrocenosis biopotential are graphically presented. The analysis of chemical and technogenic factors negative impact on agroecocenoses leading to bioresource deformations in the biocenosis, soil and soil microbiota, microbio-, acaro- and entomosystems is carried out. The necessity of restoring and developing the reproductive capabilities of agroecosystems, mainly by biological methods, is proved, which include: the development of rhizosphere microorganism populations in the soil biota, the range expansion of the applied bioproducts created on the effective strain basis of beneficial microorganisms, the widespread application of various forms and methods to increase plant immunity, including elicitor-type preparations.
\end{abstract}

\section{Introduction}

In industrial fruit growing, a set of methods and ways formed according to a certain target feature, represent a specific technology: management of photosynthetic activity (crop formation and yield optimization); protection of plantings and crops; soil maintenance (management of the nutrient status of soils and the nutrient regime of plants), etc.

Intensification in fruit growing is the qualitative improvement of the elements of the agrocenosis, production and technological processes in order to make the fullest use of the natural and biological potential, ways and methods for reducing resource costs, achieving a set of technological and economic parameters of production that provide a quantitative and qualitative increment of the result.

\footnotetext{
* Corresponding author: gayanek@mail.ru
} 


\section{Results and discussions}

The list of solvable problems is determined by a set of modern ways for increasing technological and economic efficiency, formalized in technology, and providing resources according to the methods and the formed level of technology intensity.

The world socio-economic formations are developing within the framework of technological structures characterized by a qualitatively homogeneous composition of improved means of production and the use of fundamentally new ways and methods of transforming objects of labor [1].

The main technological shifts of the technological structure formed in the domestic fruit growing are: significant variety renewal; the spread and use of a wide range of weak-growing rootstocks; differentiation of variety/rootstock combinations; resource-saving formations; new types of plantings; an increase in the scale of introduction of innovations due to an increase in the rate of renovation of plantings, etc. The predicted technological shifts in the near future should, in particular, include: a systematic increase in the resistance of cultivated plants to external stress factors and management of the productive potential of the agrocenosis based on modern methods; biologization of production processes and resource saving, including reducing the cost of living labor.

The processes of intensification and biologization are based on the most complete involvement in the reproduction of natural bioresources and increasing the biopotential of plants themselves.

The characteristic features of the strategic shape of promising technologies in fruit growing, which form scientific and practical tasks, include the dominance of digital technologies based on long-term empirical databases and modern methods of biologization:

- accurate construction of agrocenoses on the basis of system databases and databanks containing, in particular, the established parameters of the limiting factors of the cultivation area, and parametric characteristics of the traits of the variety/rootstock combination placed in the agrocenosis;

- automated regulation control of physiological, biochemical and other processes of plants themselves, the realization of their productivity potential by ways and methods of achieving optimal conditions and state;

- pathocenotic regulation based on the studied nature of pests and diseases and their life cycles, by establishing a balance of harmful and beneficial microorganisms; achievement, including on this basis, a high level of photosynthesis and product quality;

- management of soil content by developing biological systems that eliminate competition for nutrition, forming a geo-, bio-, zoocenosis that can restore soil fertility;

- mechanization of processes based on the creation of a machine-technological complex that takes into account the fundamental change of methods and ways of managing production processes.

The most relevant in solving the problems of increasing the productivity of the agrocenosis and reducing the relative costs of producing the resources involved in the process will be the ecologization, biologization and resource conservation of all technological processes, naturally, by new methods and ways: bioinformatics; biotechnologies based on molecular biology and biochemistry, genetic engineering; nanotechnologies, cellular technologies; artificial intelligence systems [2].

Performance indicators as a representation of the effects formed by priority ways in a specific functional area are signs that characterize the technology as promising (table 1) [3]. 
Table 1. Intensification of production and technological processes in industrial fruit growing

\begin{tabular}{|c|c|c|c|}
\hline \multicolumn{2}{|c|}{ Criterion-sign of intensive technologies } & \multicolumn{2}{|c|}{ Factors of process intensification } \\
\hline Criterion & Meaning & Factor & Effect \\
\hline $\begin{array}{l}\text { Quick receipt of a } \\
\text { commercial yield }\end{array}$ & $\begin{array}{l}\text { for the } \\
\text { 2nd-3rd } \\
\text { year }\end{array}$ & Rootstock & $\begin{array}{l}\text { Reducing the strength of plant } \\
\text { growth and preserving the } \\
\text { production properties of } \\
\text { varieties }\end{array}$ \\
\hline $\begin{array}{l}\text { Recoupment of original } \\
\text { costs }\end{array}$ & $\begin{array}{l}\text { for the 4th } \\
\text { year }\end{array}$ & Variety & $\begin{array}{l}\text { Adaptation to the conditions } \\
\text { of cultivation and possession } \\
\text { of a set of specified } \\
\text { economically valuable } \\
\text { characteristics }\end{array}$ \\
\hline $\begin{array}{l}\text { Stable fruiting and } \\
\text { relatively high yield }\end{array}$ & $\begin{array}{l}35-40 \text { t per } \\
\text { ha }\end{array}$ & $\begin{array}{l}\text { Planting } \\
\text { material }\end{array}$ & $\begin{array}{l}\text { Obtaining an industrial yield } \\
\text { from 2-3 years after planting }\end{array}$ \\
\hline $\begin{array}{l}\text { Profitability at the level } \\
\text { of extended reproduction } \\
\text { (profitability), which } \\
\text { provides a comparably } \\
\text { low cost of production }\end{array}$ & $\begin{array}{l}\text { More than } \\
60 \%\end{array}$ & $\begin{array}{l}\text { Planting plan } \\
\text { of trees (fruit } \\
\text { plants) }\end{array}$ & $\begin{array}{l}\text { Compliance with the growth } \\
\text { strength of the } \\
\text { variety/rootstock combination } \\
\text { and the required feeding area }\end{array}$ \\
\hline $\begin{array}{l}\text { The optimal period of } \\
\text { productive operation of } \\
\text { plantings for the } \\
\text { accumulation of funds } \\
\text { for renovation including } \\
\text { variety }\end{array}$ & $\begin{array}{l}15-17 \\
\text { years }\end{array}$ & Crown form & $\begin{array}{l}\text { Providing, depending on the } \\
\text { density of plant placement, the } \\
\text { standard level of illumination } \\
\text { of the leaf apparatus and the } \\
\text { efficiency of photosynthesis }\end{array}$ \\
\hline $\begin{array}{l}\text { The necessary fruiting } \\
\text { resource for the period of } \\
\text { commercial fruiting of } \\
\text { plantations to ensure the } \\
\text { rationality of land use }\end{array}$ & $\begin{array}{l}530 \mathrm{t} \text { per } \\
\text { ha }\end{array}$ & $\begin{array}{l}\text { Integrated } \\
\text { plant and crop } \\
\text { protection } \\
\text { system }\end{array}$ & $\begin{array}{l}\text { Reduction of chemical } \\
\text { pressure on agrocenoses and } \\
\text { the costs of protecting } \\
\text { plantings and crops }\end{array}$ \\
\hline $\begin{array}{l}\text { High commercial quality } \\
\text { of products that } \\
\text { characterize all structural } \\
\text { solutions that contribute } \\
\text { to the realization of the } \\
\text { physiological and } \\
\text { biochemical capabilities } \\
\text { of the variety/rootstock } \\
\text { combination }\end{array}$ & $\begin{array}{l}\text { The } \\
\text { standard of } \\
\text { fruits is not } \\
\text { less than } \\
90 \%\end{array}$ & $\begin{array}{l}\text { Organo- } \\
\text { mineral } \\
\text { system of soil } \\
\text { content }\end{array}$ & $\begin{array}{l}\text { Ensuring optimal plant } \\
\text { nutrition and reproduction of } \\
\text { soil fertility }\end{array}$ \\
\hline
\end{tabular}

The variety/rootstock combination, which initially forms the shape of modern technology, is a fundamental factor of intensification in fruit growing (Figure 1).

The use of intensive technologies for the cultivation of fruit crops, in particular apple trees, contributes to a more efficient use of biological and economic resources, increasing the efficiency and sustainability of reproductive processes.

The mass application of intensive technologies in industrial fruit growing dates back to the 80 s of the last century, as a result of the wide spread of weak-growing rootstocks, in particular, M9, as well as the actively carried out domestic breeding of weak-growing rootstocks. For the South of Russia, rootstocks of the SK series (North Caucasus) were created for establishing of orchard of various densities that reduce the strength of plant growth. 


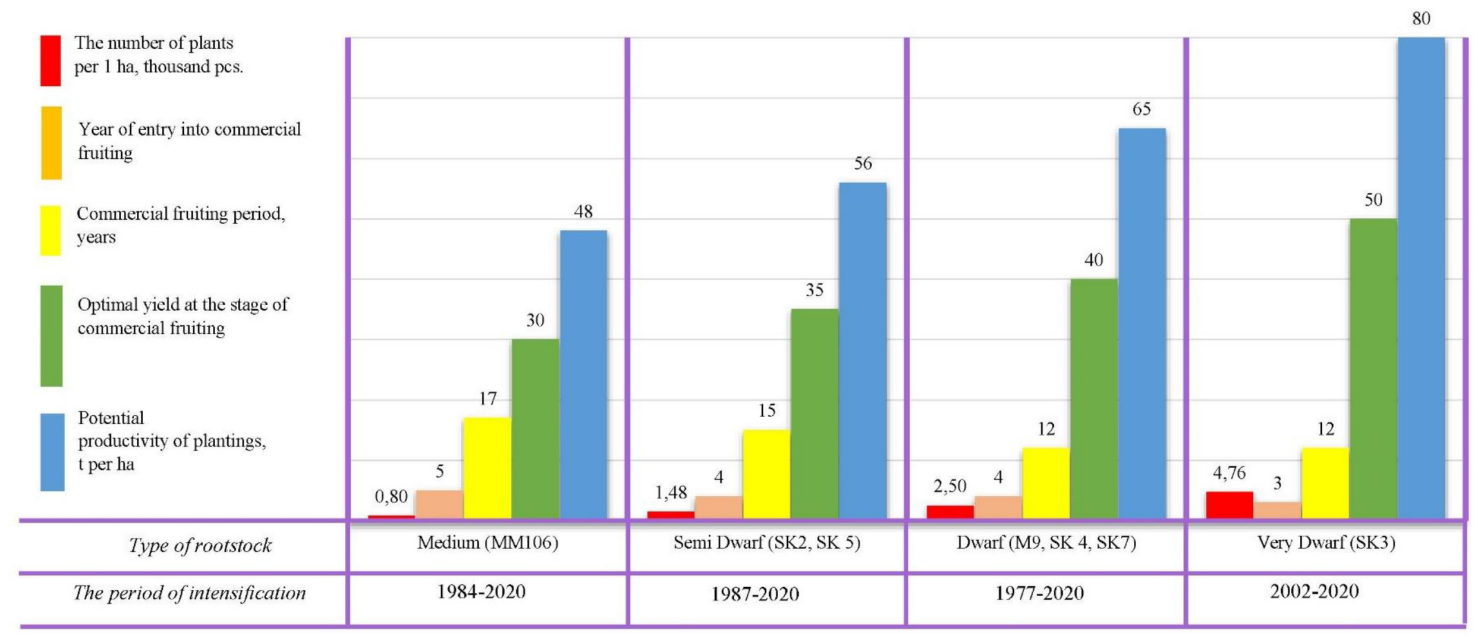

Fig. 1. Retrospective of intensification in fruit growing (apple tree culture) 
A retrospective analysis for more than forty years of the introduction of intensive technologies in fruit growing on different types of rootstocks indicates a high level of mobilization of biological resources in the forming agrocenoses. Thus, intensive technologies for cultivating apple crops on very dwarf rootstock (SK3) exceed the technology for cultivating crops on medium rootstocks (MM106) in terms of performance indicators, in particular: the potential productivity and optimal yield of plantings exceeds the analog by 70 $\%$, entry into commercial fruiting begins on the 2nd-3rd year instead of the 5 th year, the number of plants placed on 1 ha is 6 times more (Figure 2).

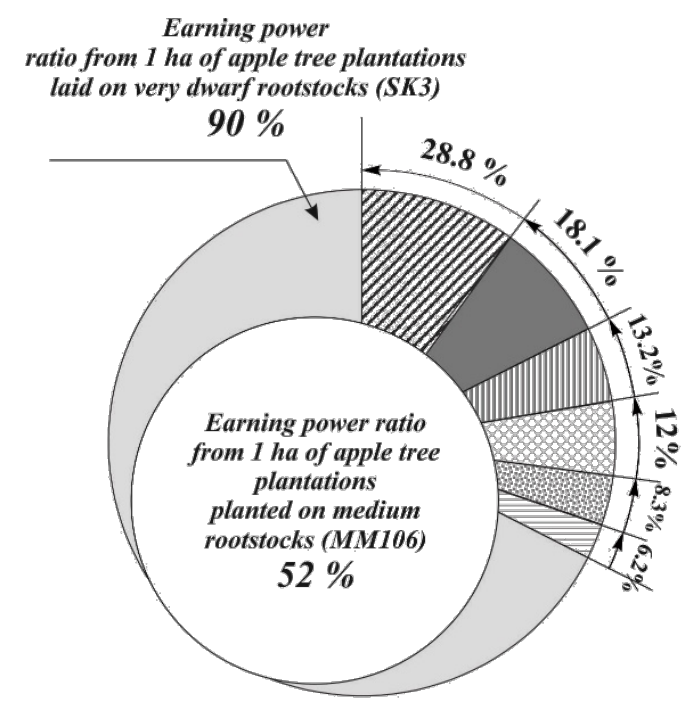

Increase in profitability $(\mathrm{P})$ (earning power ratio) by 38,1 p.p.

Increase in the volume of own revolving fund by $33.0 \%$

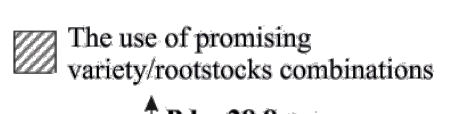

$\uparrow \mathrm{P}$ by 28.8 p.p.

An increase in the number of plants placed on 1 ha

$\uparrow P$ by 18.1 p.p.

The use of virus-free

planting material

$\uparrow$ P by 13.2 p.p.

The use of an integrated system

for the protection of plantings and crops

\section{$\uparrow$ P by 12.0 p.p.}

The use of organo-mineral system of soil content

\section{$\uparrow$ P by 8.3 p.p.}

Formation of the optimal

optical-physiological system

of the plant crown

$\uparrow$ P by 6.2 p.p.

Fig. 2. The main directions of intensification that increase the biopotential of agrocenosis

The most relevant areas of increasing the biopotential of agrocenosis are: the use of promising variety/rootstock combinations (the share of influence on efficiency is $28.8 \%$ ), the use of virus-free planting material $(13.2 \%)$, the use of an integrated system for protecting plantings and crops $(12.0 \%)$ and organo-mineral system of soil content $(8.3 \%)$, the formation of an optimal optical-physiological system of the plant crown $(6.2 \%)$, the use of which allows for an increase in the profitability of production by 38 points, an increase in the volume of own revolving fund by $33 \%$.

A significant change in the structural elements of agrocenoses, associated with the intensification of processes due to the transition of fruit growing to a new technological regime, causes positive and negative aspects of reproduction, forms bioresource deformations - a disruption dispersion of the rationality of natural resource use in agrocenoses and the sustainability agroecosystems from changes in abiotic and biotic factors.

To the fullest extent, technogenic impacts cause deformations in the main elements of agroecocenosis - biocenosis, soil and soil microbiota, pathocenosis, which is shown in strongly pronounced destructive processes - a decrease in soil fertility and biogenicity, a disruption dispersion of the stability of microbio-, acaro - and entomosystems, the immune status of cultivated crops, the inability of fruit plants to realize their productive potential. 
As a result of long-term cultivation of monoculture (perennial plantings), according to the results of the analysis of soil fertility in different fruit growing zones, the following trends are formed on different types of soils: a decrease in the content of organic matter and total humus in the soil; the predominance of mineralization of organic substances over humification processes; a decrease in the content of major nutrients; increased acidity; soil contamination with pesticide residues; soil compaction and deterioration of their agrophysical properties; disruption dispersion of microbiological processes and increased soil toxicity.

The increase in the chemical and technogenic load on fruit agrocenoses associated with the intensification of processes leads to an increase in the volume of mechanized work by $25.8 \%$ (from 113.6 vehicle-hour per ha in 2010 to 142.9 vehicle-hour per ha in 2019); the pesticide load by $9 \%$ (from $101.2 \mathrm{~kg} / \mathrm{ha}$ in 2010 to $110.3 \mathrm{~kg} / \mathrm{ha}$ in 2019 ).

Due to the complex impact of technogenic factors and changes in weather conditions, a change in the species composition of mycopathocomplexes and an increase in the harmfulness of the dominant mycoses of fruit crops was recorded [4].

As a result of the increased resistance of pathogens to the used chemicals, as well as due to the increase in the frequency of treatments associated with climate change, the volume of used plant protection chemicals and the cost of protection increases. So for the period 20152020 , there was an increase in the cost of purchased plant protection products by 1.5 times, which had an impact on reducing the efficiency of production.

Thus, with an average potential productivity of plantings laid by plants on weak-growing rootstocks of $65 \mathrm{t} / \mathrm{ha}$, the average yield over the past ten years does not exceed $26 \mathrm{t} / \mathrm{ha}$.

The main negative displays of the factors of chemical-technogenic intensification leading to bioresource deformation are: reducing the resistance of pathogens to the used chemicals, which causes an increase in the frequency of treatments, an increase in the costs of purchased plant protection products, a decrease in yield (the share of the factor's influence on the decrease in the efficiency of fruit production is on average $9 \%$ ); an increase in the technogenic load leads to an increase in the volume of mechanized work, a decrease in soil biogenicity (the share of the factor is over $25 \%$ ); a decrease in the immune status of plants causes a decrease in the potential productivity of plantings (the share of the factor is not less than $18 \%$ ) (Figure 3 ).

The increasing volume of the use of preparations of chemical origin and their accumulation in trophic connections led to a disruption dispersion of the biological balance in the ecosystems of agrocenoses, became an additional damaging factor of plants, created prerequisites for a decrease in their immune status and obstacles to the realization of their productive potential $[4,5]$.

Taking into account the direct relationship between the state of the agrocenosis, the level of realization of the reproductive potential and chemical and technogenic impacts, attention should be focused on the fact that the intensification of processes should be carried out mainly by biological methods.

That statement of tasks shifts the emphasis and actualizes the need to adjust the methods of intensification, i.e. to achieve appropriate effects in certain areas [7].

In ensuring the sustainability of agroecosystems, priority is given to biologization as the "main manifestation of ecologization" [8], the use of living organisms, their systems, and their life products to solve technological problems.

Thus, ecologization is the process of restoring the reproductive capabilities of agroecosystems, and biologization is the ways to achieve technological and economic efficiency. 


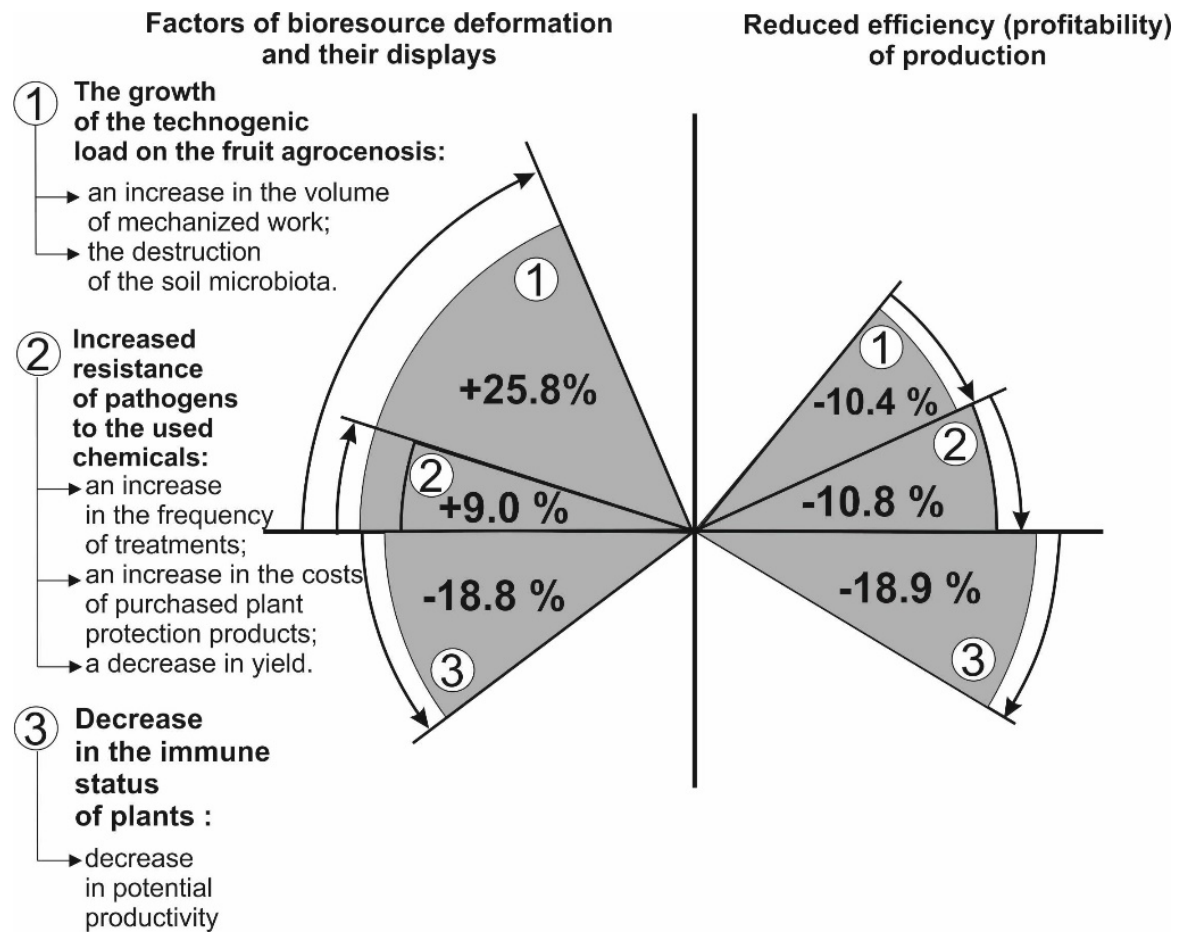

Fig. 3. Negative displays of chemical-technogenic intensification factors leading to bioresource deformation of the agrocenosis

Minimizing the negative anthropogenic impact on agroecosystems during the implementation of reproduction processes should also be of a regulatory character, which requires more in-depth and substantive studies of the areas of technogenic impacts.

To increase the biogenicity of the soil, measures are being taken to develop populations of beneficial microorganisms $[9,10]$.

The interaction of plants with symbiotic and beneficial rhizosphere microorganisms plays an important role, since specific relationships develop between them, productive relationships with a variety of functional displays are determined [11].

In reducing the chemical pressure on agroecosystems, the emphasis in protection systems is shifting towards biologization.

The biorational system for the protection of perennial plantings is based on newgeneration preparations, the application of bioagents at vulnerable stages of the development of pests and diseases, an operational assessment of their application for the entire complex of useful species in combination with established communication links in the agroecosystem [7].

The indicators of the biological effectiveness of protective measures with an optimal combination in the system of biological and chemical protection tools are almost identical [7].

Modern biological products created on the basis of effective strains of beneficial microorganisms are used to ensure the vital activity of various and, first of all, the main components of agrocenoses, to increase the efficiency of reproductive processes [12-14].

The use of biological methods of intensification in the field of plant protection will increase quantitative indicators (plant productivity by 1.4 times), significantly change qualitative indicators: improve the state of the agroecosystem, prevent a decrease in 
sensitivity to insecticides in pests, optimize production processes, increase the efficiency of production processes.

In solving the problem of increasing the stability of biocenoses, attention should be focused on the wide use of various forms and methods of increasing plant immunity, reducing damage to plants by active oxygen forms with a sharp change in their physiological state, by strengthening antioxidant protection, including: treatment with natural and synthetic antioxidants, analogues of phytohormones and salicylic acid, which induces the expression of genes of antioxidant enzymes that increase resistance to subsequent oxidative stress, increases the resistance of plants to abiotic and biotic stressors [15].

These trends actualize the need to develop technologies for the application of new biologically active preparations such as elicitors, both abiogenic and biogenic, which, together with other effects, makes it possible to increase the resistance of plants to abiotic and biotic stressors [3]. As a result of treatment with immunizers, the resistance of plants to diseases and pests increases, the amount of pesticides decreases and the profitability of fruit production (apples during winter ripening) increases by more than 6 points.

\section{Conclusions}

The application of preparations that are immunizers and retardants on winter apple varieties allows to increase winter and drought resistance, yield by an average of $40 \%$ and increase the standard of fruits by 11.2 percentage points. to ensure a reduction in the cost of production by $14.8 \%$; an increase in the profitability of the product by 22.4 points [3].

Various methods and ways of biologization of production and technological processes in industrial fruit growing, based on the use of living organisms, their systems, products of their vital activity in solving technological problems, allows not only to restore the bioresource potential of the agrocenosis achieved by chemical and technogenic methods of intensification, but also to form higher reproductive capabilities of the agroecocenosis, which have a significant reserve of plasticity potential, ensuring optimal technological and economic efficiency.

Acknowledgement. The research was carried out with the financial support of the Ministry of Science and Higher Education of the Russian Federation.

\section{References}

1. M. Rusu-Tanasă, Procedia Econ. Financ., 27, 369-374 (2015). http://doi.org/10.1016/S2212-5671(15)01008-4

2. E. Egorov., Zh. Shadrina, G. Kochyan, BIO Web Conf., 25, 01001 (2020) https://doi.org/10.1051/bioconf/20202501001

3. E.A. Egorov, Zh.A. Shadrina, G.A. Kochyan, Scientific Works of NCFSCHVW, 17, 719 (2018) http://doi.org/10.30679/2587-9847-2018-17-7-19

4. E. A. Egorov, L. L. Buntsevich, Horticulture and viticulture, 2, 39-42 (2018). https://doi.org/10.25556/VSTISP.2018.2.12305

5. S. Jiménez, M. Fattahi, K. Bedis, S. Nasrolahpour-Moghadam, J.J. Irigoyen, Y. Gogorcena, Front. Plant Sci., 11, 43 (2020) https://doi.org/10.3389/fpls.2020.00043

6. R.F. Doornbos, L.C. van Loon, P.A.H.M. Bakker, Agron. Sustain. Dev., 32, 227-243 (2011). http://doi.org/10.1007/s13593-011-0028-y

7. E. A. Egorov, Zh. A. Shadrina, G. A. Kochyan, R. A. Shichiyakh, Proceedings of the Kuban State Agrarian University, 77, 29-34 (2019) http://doi.org/10.21515/1999-170377-29-34 
8. Y. Wang, W. Li, X. Xu, C. Qiu, T. Wu, Q. Wei, F. Ma, Z. Han, Hortic. Plant J., 5 (5), 183-191 (2019) https://doi.org/10.1016/j.hpj.2019.06.001

9. F. Abtahi, M. Shams-Bakhsh, N. Safaie C. R. Autonell, C. Ratti, J. Agr. Sci. Tech., 19(1), 217-230 (2017) https://jast.modares.ac.ir/article-23-12393-en.pdf

10. N.R. Dalezios, A. Blanta, N.V. Spyropoulos, A.M. Tarquis, Nat. Hazards Earth Syst. Sci., 14(9), 2435-2448 (2014) https://doi.org/10.5194/nhess-14-2435-2014

11. P. Kaur, A. Kumar, V. Arora, Plant Cell Biotechnol. Mol. Biol., 21(63-64), 140-150 (2020) https://ikprress.org/index.php/PCBMB/article/view/5677

12. M. Ghorbanpour, M. Omidvari, P. Abbaszadeh-Dahaji, R. Omidvar, K. Kariman, Biol. Control, 117, 147-157 (2018) http://doi.org/10.1016/j.biocontrol.2017.11.006

13. R.C. Gergerich, R.A. Welliver, N.K. Osterbauer, S. Kamenidou, R.R. Martin, D.A. Golino, K.C. Eastwell, M. Fuchs, G. Vidalakis, I. E. Tzanetakis, Plant dis., 99 (2), 176187 (2015) http://doi.org/10.1094/PDIS-07-14-0762-FE

14. D.A. Edge-Garza, J.J. Luby, C. Peace, Mol. breeding, 35(12), 223 (2015) https://doi.org/10.1007/s11032-015-0409-z

15. E.I. Koshkin, G.G. Guseinov, Ecological physiology of agricultural crops: textbook, 576 (RG-Press, Moscow, 2020) http://doi.org/10.31085/9785998808418-2020-576 